\title{
Infrastructure procurement skills gap amongst procurement personnel in Nigeria's public sector
}

DOI:

10.1108/JEDT-09-2017-0089

\section{Document Version}

Accepted author manuscript

Link to publication record in Manchester Research Explorer

\section{Citation for published version (APA):}

Mahamadu, A. M., Manu, P., Booth, C., Olomolaiye, P., Coker, A., Ibrahim, A., \& Lamond, J. (2018). Infrastructure procurement skills gap amongst procurement personnel in Nigeria's public sector. Journal of Engineering, Design and Technology, 16(1), 2-24. https://doi.org/10.1108/JEDT-09-2017-0089

\section{Published in:}

Journal of Engineering, Design and Technology

\section{Citing this paper}

Please note that where the full-text provided on Manchester Research Explorer is the Author Accepted Manuscript or Proof version this may differ from the final Published version. If citing, it is advised that you check and use the publisher's definitive version.

\section{General rights}

Copyright and moral rights for the publications made accessible in the Research Explorer are retained by the authors and/or other copyright owners and it is a condition of accessing publications that users recognise and abide by the legal requirements associated with these rights.

\section{Takedown policy}

If you believe that this document breaches copyright please refer to the University of Manchester's Takedown Procedures [http://man.ac.uk/04Y6Bo] or contact uml.scholarlycommunications@manchester.ac.uk providing relevant details, so we can investigate your claim.

\section{OPEN ACCESS}




\section{INFRASTRUCTURE PROCUREMENT SKILLS GAP AMONGST PROCUREMENT PERSONNEL IN NIGERIA'S PUBLIC SECTOR}

Purpose - Procurement of public infrastructure that is fit for purpose partly depends on the competencies of procurement personnel. In many developing countries in SubSaharan Africa, including Nigeria, there is a deficit in the quantity and quality of infrastructure and their procurement is further riddled with deficiencies in the capacity of public procuring entities. It is, however, unclear from the extant literature, what are the critical skills development needs of public personnel involved in the procurement of infrastructure in Nigeria.

Design/methodology/approach - Based on a quantitative research strategy, this study sought to address the knowledge gap through a survey of public infrastructure procurement personnel $(n=288)$ in different tiers of government (i.e. state and local government) and geopolitical contexts (north and south) in Nigeria.

Findings - Of the 45 procurement skill areas operationalised, there is need for further development in 38 of them including: computing/ICT; problem solving; communication; decision making; health and safety management; quality management; relationship management; team building; project monitoring and evaluation; time management; and procurement planning.

Originality/value - A key implication of this study is for policy makers in state and local government to formulate and implement infrastructure procurement capacity development reforms that address the competency gaps of procurement personnel. Such reforms need to take into account the suitable methods for developing procurement competencies. Additionally, the procurement skill areas operationalised in this capacity assessment study could serve as a useful blueprint for studying capacity deficiencies amongst public infrastructure procurement personnel in other developing countries.

Keywords: Developing country; procurement skills; infrastructure; Nigeria; subSaharan Africa.

\section{Introduction}

Whilst the provision of municipal services is crucial to the attainment of the United Nations Sustainable Development Goals (SDGs), such as the provision of good health and well-being, clean water and sanitation, quality education, and affordable and clean energy for urban populations and communities (United Nations Economic and Social Council, 2016), it is dependent on the effective procurement of critical infrastructure, such as water and waste treatment, power generation, transport, health, and educational infrastructures. In developing countries, especially in Sub-Saharan Africa, there is a deficit in the quantity and quality of these infrastructures (see South Africa's National Infrastructure Plan (Presidential Infrastructure Coordinating Commission, 2012)). The situation in Nigeria is not dissimilar (African Development Bank (AfDB), 2013).

Besides the deficits in infrastructure in Nigeria, their procurement is further riddled with an array of challenges including deficiencies in the capacity of public procuring entities 
(World Bank, 2013). It has been estimated that by 2025 global construction output would increase by $70 \%$ to USD $\$ 15$ trillion (Global Construction Perspectives and Oxford Economics, 2013). Part of this unprecedented growth is expected to be experienced in developing countries as investments are made to address infrastructure deficits. Given that public procurement is one of the important vehicles for realising infrastructure assets that are intended to deliver socio-economic benefits, it is paramount that attention is given to the procurement capacity of public procurement entities. This study aimed to establish the critical gaps in the skills of public personnel involved in the procurement of public infrastructure in Nigeria.

In the sections that follow, a review of Nigeria's infrastructure outlook and public procurement is presented. The review is extended to cover procurement capacity literature, in particular skills, in order to draw out procurement skills and methods of skills development. Subsequent to this, the research strategy applied in this study, the ensuing findings, discussion, implications and concluding remarks are given.

\section{Nigeria's Infrastructure Outlook and Public Procurement}

Nigeria's infrastructure deficit remains high despite capital investment of up to US $\$ 5.9$ billion per year, as well as programmes such as the National Integrated Infrastructure Master Plan (NIIMP), which is estimated to cost US\$2.9 trillion over the next 30 years (Veitch, 2014). The state of Nigeria's infrastructure remains poor and has resulted in poor municipal service delivery (Agu and Onodugo, 2009; Foster and Pushak, 2011). For example, as a result of acute shortages in power generation infrastructure, the average per capita consumption of electricity is only about $150 \mathrm{kWh}$ per annum compared to the UK average of $5,500 \mathrm{kWh}$ (Veitch, 2014). Furthermore, small scale renewable energy generation has not been adequately exploited in Nigeria (AfDB, 2013). Housing deficit in Nigeria is estimated at 17 million units (Veitch, 2014). With regards to transportation, only $18 \%$ of Nigeria's estimated $197,000 \mathrm{~km}$ of roads is paved; and about 53 percent of the rural population live more than two $\mathrm{km}$ away from an all-season road (AfDB, 2013). The state of water, sanitation, education and health infrastructure is also regarded as poor due to years of neglect and ineffective allocation of resources for their procurement (Foster and Pushak, 2011). In order to stimulate the required socio-economic growth there is a need for sustained investment through procurement across all levels of government (i.e. Federal, State and Local Government). Evidence, however, points to procurement capacity deficiency in Nigeria (World Bank, 1995, 2000; Agu and Onodugo, 2009; Adewole, 2014).

The evolution of procurement practices in Nigeria and other developing countries has been on the back of the enactments of legal and regulatory frameworks to improve on previously unregulated and ineffective procurement procedures (Adewole, 2014). Developments that led to the evolution in the public procurement regime in Nigeria include the World Bank's (2000, pp. 26-30) procurement assessment, which identified challenges in public procurement including: "proliferation and ineffectiveness of tender boards; lack of professionalism in the execution of the procurement functions; weaknesses in bank financed projects; excessive deposit for opening of letters of credit; lack of communication strategy; weaknesses in the export, import and tariff procedures; lack of streamlined quality control practices; and lack of knowledge in electronic procurement in the public sector".

To alleviate these challenges, attention has mainly focussed on the formulation of regulatory and legal frameworks to ensure transparency, accountability, anti- 
corruption and the achievement of assets that are fit for purpose. Prominent amongst the legal frameworks is the Public Procurement Act 2007 (PPA 2007). The PPA 2007 harmonises existing government practices and policies for public procurement. It has 13 parts and 61 sections, with the broad aim of dealing exhaustively with all issues related to transparency and integrity in public procurement. Despite promotion of the PPA 2007 by the federal government, donor and civil society organisations, it has not been enacted by all the states in Nigeria (Adewole, 2014).

\section{Procurement Capacity}

Procurement capacity or capability development has been described by the United Nations (UN) as the process through which individuals, organisations and societies obtain, strengthen, and maintain the capabilities to set and achieve their own development objectives over time (United Nations Development Programme (UNDP), 2010). Procurement capacity can be conceptualised as comprising three interconnected facets: individual; organisational; and environmental/national (see Organisation for Economic Co-operation and Development (OECD) and World Bank 2004; UNDP, 2010). The individual facet, which is pertinent to this study, looks at the skills, knowledge and experience of procurement personnel.

Individual capacity is regarded as a critical aspect of a public agency's procurement function (Lamptey and Elle, 2000). The increasing scope of procurement requires a workforce with the requisite skills, as well as knowledge of trends in the technologies necessary for managing modern procurement (Addo-Duah et al., 2014). The World Bank (2003) has drawn a link between the reliance on untrained procurement staff and the misapplication of the procurement procedures and sometimes unethical practices in procurement systems in developing countries. According to Appiah (2011), no matter how robust the regulation or law on public sector procurement, its effective application depends largely on a trained and skilled workforce. Attempts to determine and develop skills to meet changes in public sector procurement practice are not a recent phenomenon (Addo-Duah et al., 2014). Yet, there is no global "onestop-shop" or central reference point of procurement skills for consistency in terms of capability development policy (Giunipero and Pearcy, 2000). Nevertheless, several skills have been proposed to meet the needs of the changing role of procurement. Modern procurement requires skills related to market focus, value derivation, life cycle thinking, sustainability and the application of information technology (Giunipero et al., 2006; Basheka, 2010; Addo-dual et al., 2014). Consequently, skills required for procurement have become increasingly multi-disciplinary and cut across technical, strategic, interpersonal and managerial skills (Tassabehji and Moorhouse, 2008). Table 1 offers a list of skills (drawn from various literature sources) required to meet these modern expectations of procurement.

Despite the requirement of Nigeria's Bureau of Public Procurement (BPP) to organise training and human resource development programmes for procurement personnel (see PPA, 2007), it is unclear what skills deficiencies exist, as well as the most appropriate methods for their development. The approaches listed in Table 2 have been suggested within procurement capacity literature for acquiring and updating knowledge and skills for modern procurement. 
Table 1: Skills for Procurement

[Insert Table]

Table 2: Methods for Skills or Competency Development

[Insert Table]

\section{Methodology}

Aligned to the study's aim, the study sought to gain a generic view of the skills development needs of public personnel involved in the procurement of infrastructure in Nigeria. In such instance, Fellows and Lui (2008) and Creswell (2009) explain that quantitative research, as opposed to qualitative research which is aligned to the provision of meaning of phenomenon, is most appropriate as quantitative research is suitable for obtaining a generalised view of a phenomenon. Consequently, a quantitative research strategy, particularly a survey was adopted. The use of a quantitative strategy for this study implied that the key phenomenon under investigation (i.e. procurement capacity needs) was being viewed as a "single reality" which can be observed and assessed objectively. Qualitative approaches are more concerned with the discovery of subjective reality and feelings (Fellows and Liu, 2008), thus being unsuitable for the study's aim. Furthermore, quantitative survey has been the preferred approach for similar procurement capacity investigations (e.g. Basheka, 2010; Addo-Duah et al., 2014). In this study, the use of a cross-sectional survey thus enabled the capture of the experiences and perceptions of a wide range of public personnel who are involved in the procurement of infrastructure. Details of the survey design are presented below.

\section{Survey design}

A questionnaire was designed for the survey. It consisted of three main parts:

Part 1 - Background Information: This part was designed to capture respondents' background information, as well as the public agencies they work for. The individual background information solicited included procurement role, experience in role, experience in procurement of infrastructure, the types of infrastructure respondents are involved in their procurement, type of respondents' organisation (i.e. state or local government agency), and location of the organisation (northern or southern geopolitical zone). Type of organisation was important to consider due to indication in the literature that there are differences in the capacity of different tiers of government agencies in Nigeria (Adewole, 2014). Also, personnel in procurement entities in different geopolitical locations (north and south Nigeria) was worthy of consideration to enable comparative exploration of skills gap, i.e. whether personnel in a location have greater skill deficiencies than those in another location.

Part 2 - Infrastructure Procurement Skills Gaps: This part was two-pronged. The initial section inquired into the procurement personnel's perceptions regarding the importance of a list of procurement skills, and the subsequent section examined their development needs regarding the procurement skills/competencies. Drawing from the literature, 45 skills (shown by Table 1 ) were operationalised. For the initial section a five-point Likert scale ( 1 = strongly disagree; 2 = disagree; 3 = neutral; 4 = agree; 5 = 
strongly agree) was used to ascertain the extent to which the personnel agree that the skills are important to the discharge of their procurement role. For the second section, a five-point Likert scale (i.e. $1=$ not required at all; $2=$ slightly required; $3=$ moderately required; 4 = required; and 5 = highly required) was also used to ascertain the extent to which personnel require further development in each of the 45 skills. This was to establish the critical gaps in the skills of public personnel involved in the procurement of infrastructure.

Part 3 - Approaches for Procurement Skills Development: This part sought to identify the most appropriate methods for the development of infrastructure procurement skills. Drawing from the literature, 15 skills development methods (shown by Table 2) were operationalised. Respondents were asked to indicate on a five-point Likert scale (i.e. $1=$ not suitable at all; 2 = slightly suitable; 3 = moderately suitable; 4 = suitable; and $5=$ highly suitable) the extent to which each of the 15 methods are suitable for developing their procurement skills needs. Additionally, respondents were asked to indicate whether they have participated in any procurement related career development activities in the past two years.

Two state locales in Nigeria were used for the study: Kaduna State (in northern Nigeria) and Oyo State (in southern Nigeria). These locales were selected for being homes to major cities in Nigeria (Kaduna city and Zaria in Kaduna State, and Ibadan in Oyo State). Additionally, development plans for the states have highlighted acute infrastructure deficits (Oyo State Government, 2010; Kaduna State Government, 2013). The survey was administered from July - September 2016 by hand delivery to personnel involved in infrastructure procurement within local government authorities' works departments, as well as within state ministries and agencies. It was expected that such personnel would include a range of built environment and procurement personnel e.g. urban/town planners, architects, civil/structural engineers, quantity surveyors, project managers, electrical engineers, and personnel acting in the capacities of project sponsors, senior responsible owners and investment decision makers who are often involved in the initiation, planning, design/specification, execution, and evaluation phases of municipal infrastructure procurement. Overall, 373 questionnaires (comprising 195 in the north, and 178 in the south) were administered and 117 (for the north) and 178 (for the south) were retrieved by hand collection. Following screening of the questionnaire and missing data analysis, 7 of the southern questionnaires were excluded. The effective sample sizes and response rates are: north -117 and $60.0 \%$; south -177 and $96.1 \%$; and overall sample - 288 and $97.6 \%$.

\section{Data analysis}

The questionnaire data were coded into IBM SPSS Statistic 23 for analysis. SPSS was used to undertake descriptive statistical analyses (e.g. frequencies, mean and standard deviation) and inferential statistical analyses - t-tests. T-test allows the statistical examination of two sample means (Field, 2013), and has been applied in previous studies examining critical competencies of construction professionals (See Ahadzie et al., 2008). In this study, the one-sample t-test was carried out to determine whether the sample population considered a specific skill or method of acquiring the skill to be important or otherwise as well as determine skills requiring further development in the opinion of procurement professionals. The null hypothesis for assessing important procurement skills was that the skill is not important $\left(H_{0}: U=U_{0}\right)$ 
and the alternative hypothesis was that the skill was important $\left(H_{a}: U>U_{0}\right)$, where $U_{0}$ is the population mean ( $U_{0}$ was fixed at 3.5, drawing from Ling, 2002 and Ahadzie et al., 2008). Thus, based on the five-point Likert rating scale (1 = strongly disagree; $2=$ disagree; 3 = neutral; 4 = agree; 5 = strongly agree), a skill was deemed to be important if it had a mean score that is significantly greater than 3.5 (which approximates to 4 i.e. "agree" that a skill is important). Similarly, the one-sample t-test (with test value 3.5) was applied to establish the skills in which further development is required. Thus, based on the five-point Likert rating scale (i.e. $1=$ not required at all; 2 = slightly required; 3 = moderately required; 4 = required; and 5 = highly required), a skill was deemed to require further development if it had a mean score that is significantly greater than 3.5 (which approximates to 4 i.e. "required" on the five-point scale). The same approach was also applied to ascertain the most suitable methods for developing the procurement skills needs. Furthermore, independent samples ttests were conducted to enable the examination of the statistically significant variations in perceptions of skills development needs across different demographic sub groupings, particularly the different tiers of government and geo-political locations of the procurement personnel. The mean for each variable (i.e. skill and methods of acquisition of skills) including the associated standard deviation and standard error is also reported.

\section{Findings}

The findings of the data analyses are given below under three main sections: background information; procurement skills development needs; and suitable methods for developing procurement skills.

\section{Background Information}

A majority of the 288 respondents in the survey are engineers (35.1\%), followed by quantity surveyors (12.8\%), administrators (12.8\%), architects $(8.3 \%)$, builders $(8.3 \%)$, other roles $(6.3 \%)$, estate surveyors $(5.2 \%)$, urban/town planners $(4.9 \%)$, land surveyors (1.0\%), purchasing officer/personnel (1.0\%), and procurement officer/personnel ( $4.2 \%$ ). The other roles include geologist, engineering technologist, hydrologist, accountant, agriculturist, and environmental health officer. A majority of the respondents (i.e. 82.9\%) have been in their roles for over 5 years. The Mean experience in role is 13.48 years (standard deviation $(S D)=7.21$ ). Similar to the experience in role, a majority of the respondents (i.e. $66.2 \%$ ) have over 5 years of experience in procurement of infrastructure. The Mean experience in procurement of infrastructure is 9.51 years $(S D=6.166)$. The survey participants are mostly involved in the procurement of housing infrastructure (approximately 38\%), followed by power generation and electricity infrastructure (approximately $26 \%$ ), education infrastructure (approximately 23\%), transport infrastructure (approximately 20\%), water and sanitation infrastructure (approximately 16\%), and health infrastructure (approximately $7 \%$ ). The distribution of respondents within local government agencies and state government organisations is $52.1 \%$ and $47.9 \%$ respectively. The distribution of respondents in organisations in the south and north is $59.4 \%$ and $40.6 \%$ respectively.

\section{Procurement Skills Development Needs}

Results on the skills that are perceived by respondents to be important are shown in Table 3. From Table 3, the respondents are generally of the view that nearly all $(93.3 \%)$ of the 45 procurement skills that were examined are important to their infrastructure procurement function. The topmost important skills include: 
Communication (oral/written); Quality management; Project monitoring and auditing/evaluation; Team building; Decision making. The following were, however, not considered to be important to the procurement of infrastructure: Application of international procurement law and procedures; Responsible sourcing/Green purchasing/Green procurement; and Cross cultural awareness.

The survey ascertained respondents' deficient procurement skills. This was achieved through an assessment of the extent to which respondents felt they needed further development in each of the 45 skills examined by the survey. The results of a onesample t-test are shown in Table 4. For 38 out of the 45 skills examined, there is need for further development. Amongst the topmost skills/competencies requiring further development are: Computing IICT; Problem solving; Communication (oral/written); Decision making; Health and safety management; Quality management, Relationship management; Team building; Project monitoring and auditing/evaluation; and Time management. In the opinion of respondents, the skills that require least further development include: Business case development; Responsible sourcing/Green purchasing/Green procurement; Cross cultural awareness; Application of corporate social responsibility procedures; Application of international procurement law and procedures; Stress management; and E-procurement.

Independent-samples t-test was used to ascertain if there were statistically significant differences in the levels of development required for procurement skills/competencies between: (1) state level personnel and local government personnel; and (2) the procurement personnel in the north and the personnel in the south. The results are shown by Tables 5 and 6 . For the sake of brevity only the significant results (i.e. where the $p$-value for the t-statistic is $\leq 0.05$ ) are shown. From Table 5 the skills that were identified to be significantly more deficient amongst the state than local government personnel are: Proposal evaluation; Procurement planning; Application of national procurement law and procedures; Application of modern integrated procurement procedures; Risk management; Responsible sourcing/Green purchasing/Green procurement; and Application of ethics guidelines in procurement. Conversely, Marketing was found to be significantly more deficient among local government personnel than state government personnel. From Table 6 the skills that were identified to be significantly more deficient amongst the southern personnel than the northern personnel are: Creative thinking; Business case development; Cross cultural awareness; Stress management; Environmental management; and Health and safety management. Conversely, the only skill that was found to be significantly more deficient amongst the northern personnel than the southern personnel is: Contract management and enforcement.

\section{Methods for Developing Procurement Skills}

Respondents rated several methods of acquiring and updating procurement skills. A one-sample t-test was conducted to ascertain the methods perceived by respondents as being suitable for developing procurement skills. Methods with Mean scores that are statistically significantly greater than the test value of 3.5 were deemed suitable (see Ahadzie et al., 2008). From the test results (shown by Table 7) 11 out of 15 methods were deemed suitable by respondents. Attendance of conferences and workshops was the most suitable method followed by Networking and sharing ideas 
with other professionals, On-the-job-training, Further / Higher academic degree courses, and Work team retreats. Distant/Online learning, Apprenticeships, Internships and placements, and Job rotation or secondment were not regarded as suitable by the respondents. Regarding participation in procurement career development, a limited proportion (i.e. about $25 \%$ ) of the respondents alluded to having personally participated in any procurement related career development activities in the past 2 years. 
Table 3: Important Skills for Infrastructure Procurement

[Insert Table]

Table 4: Skills Development Needs for Infrastructure Procurement

[Insert Table]

Table 5: Differences in Perceived Infrastructure Procurement Skills Development Needs - By Type of Organisation

[Insert Table]

Table 6: Differences in Perceived Infrastructure Procurement Skills Development Needs - By Location

[Insert Table]

Table 7: Suitable Methods for Development of Infrastructure Procurement Skills

[Insert Table]

\section{Discussion}

From Table 3, strategic skills (e.g. decision making and leadership) and interpersonal skills (e.g. communication and team building) are ranked amongst the most important skills in the opinion of public procurement personnel in state and local government agencies (SLGAs) in Nigeria. There appears to be a realisation of the changing role of procurement from technical and operational procedures towards more tactical and strategic functions. This is contrary to previous studies that have highlighted seemingly lack of appreciation of the changing role of procurement in developing countries (see Basheka, 2010; Addo-Duah et al., 2014). The study has revealed a relatively adept group of procurement professionals in the Nigerian context. However, despite their high recognition of the importance of the procurement skills investigated in this study, there is an apparent disregard for some procurement competencies that are generally viewed as critical to modern procurement, notably responsible sourcing/green procurement/green purchasing (see OGC, 2007; Glass, 2011; Mensah and Ameyaw, 2012; Upstill-Goddard et al., 2015).

In the opinion of the respondents, seven skill areas require the least further development (Table 4). From Table 3 these are also amongst those viewed as being the least important. This could thus explain why respondents do not consider the need for further development in the seven skills, rather than an interpretation that they feel competent in those skills. From the findings, the skill deficiencies cut across SLGAs and across personnel in the north and south. The types of deficient skills also cut across operational and strategic skills. Some key interpersonal skills also emerged as areas where public procurement staff require further development. These include Communication, Team building, and Relationship management. This suggests efforts to develop a cadre of highly skilled procurement professionals with the requisite technical and interpersonal skills since the commencement of procurement reforms 
through the PPA 2007 may not have yet had the necessary impact on individuals at the state and local government levels. The findings, however, indicate that capacity challenges are still rife in state and local government infrastructure procurement entities even with regards to several technical skills e.g. Quality management, Contract management and enforcement, Project monitoring and auditing/evaluation, Computing IICT, Application of national procurement laws and procedures, and Tendering. This is surprising given that individual capacity building efforts by governmental initiatives often focussed on technical aspects (see World Bank, 2013).

Existence of technical skill gaps amongst the public procurement personnel gives credence to the inadequate positive impact of procurement reform at the lower tiers of government, as well as on individual personnel capacity building (Agu and Onodugo, 2009). This is further evidenced by the finding that a majority of procurement personnel have not participated in any procurement related career development activities in the past 2 years, despite the acknowledgement of the need for individual capacity development in national procurement regulatory and management frameworks (see PPA, 2007; World Bank, 2013; BPP, 2016). More so, deficiencies exist in arguably basic technical procurement skills, such as Proposal evaluation, and surprisingly this is even more evident among the state organisation personnel than the local government personnel. Furthermore, other skill deficiencies (e.g. Procurement planning) were also found to be more pronounced among the state government personnel despite reports in literature, which suggests that local government agencies would be relatively more deficient in capacity than state government agencies (Adewole, 2014).

Concerning methods for personnel capacity building, distance/online learning, an ICT mode of capacity building, is not regarded as being suitable for developing infrastructure procurement skills. This is, however, understandable given that the respondents admitted to needing further development in Computing/ICT skills. Conferences and workshop attendance, and Networking and sharing ideas with other professionals were found to be amongst the most suitable methods for procurement skills development. There was also acknowledgement of the suitability of work-based professional development methods, particularly on-the-job training. However, skills development methods such as apprenticeships, internships and placements were not deemed suitable. This could be because these methods are usually used for introducing and training new personnel into roles, while a majority of the respondents are established in their roles as shown by their years of experience in role and also years of experience in procurement.

\section{Implications of Findings}

Overall, the above research outcomes provide capacity-building insights within the Nigerian context that could be leveraged by public procurement entities in Nigeria's state and local governance structure. Aligned to this are the following implications:

- Policy makers at state and local government levels would have to formulate procurement capacity development plan(s) covering appropriate short and long-term capacity development goals and clear performance measures to guide implementation of capacity building reforms. Such plans would have to recognise the key areas of personnel procurement skills gaps. 
- To facilitate actual implementation of the plans, the plans would have to be cascaded down into well-resourced and structured operational components with appropriate schemes and programmes that will address the set performance measures and goals. For instance, periodic skills audits by state and local government public procurement entities would be beneficial in providing up-to-date and clear indications of the capacity of their staff.

- There is a need for recognition that individual procurement capacity transcends technical skills. Efforts towards promotion of individual capacity building need to recognise the strategic functions of procurement. Additionally, interpersonal or soft skills need to be part of procurement skills development programmes, curricula and initiatives in Nigeria.

- Procurement skills development initiatives would benefit from being designed to take into account the suitable methods of skills development.

Whilst the findings of the study are based on data from Nigeria, they could provide some insights for other developing countries, especially those in Sub-Saharan Africa that are implementing or undergoing public procurement reforms. For instance, the list of procurement skill areas and methods of skills acquisition employed in this capacity assessment study could serve as a useful blueprint for studying capacity deficiencies amongst public procurement personnel in other developing countries.

\section{Conclusions}

The successful procurement of public infrastructure is inextricably linked to the skills of procurement personnel. In this vein, an understanding of the skills development needs of procurement personnel is crucial. However, within the extant literature there is limited empirical indication as to the procurement skills gaps for public procurement personnel in Nigeria. Through a survey of public personnel involved in infrastructure procurement within Nigerian state and local government agencies, this inquiry has revealed circa 40 technical and interpersonal skills that are perceived by procurement personnel to be important for the procurement of public infrastructure in Nigeria. Amongst the topmost important skills are: communication; quality management; project monitoring and auditing/evaluation; team building; decision making; leadership; value engineering; health and safety management; computing/ICT; and problem solving.

The study has also shown that there is an acute need for procurement skills development amongst public infrastructure procurement personnel. Out of 45 procurement skills that were examined, there is need for further development in 38 of them. Whilst the areas of development cover both technical and interpersonal skills, interpersonal skills feature prominently amongst the topmost skill development areas. The type of organisation (i.e. local and state government) and location of organisation where personnel is based (i.e. north or southern Nigeria) seem to have limited bearing on the skills development needs of personnel.

Regarding methods for procurement skills development, conferences and workshop attendance, networking and sharing ideas with other professionals, and on-the-job 
training are perceived by public procurement personnel to be amongst the most suitable methods. Distant/online learning, apprenticeships, internships and placements, and job rotation or secondment are perceived to be unsuitable. Overall, these findings provide insights that could be leveraged by public sector infrastructure procurement agencies in Nigeria to enable them to continuously augment the capacity of their procurement personnel.

Whilst the context of the study (i.e. Nigeria) does not permit generalisability of the findings to other developing countries, the execution of the study, particularly the procurement skill areas and the methods of skills development examined, could provide a useful blueprint for the empirical assessment of the capacity constraints of public personnel involved in the procurement of infrastructure in other developing countries.

\section{References}

Addo-Duah, P., Westcott, T., Mason, J., Booth, C. A., and Mahamadu, A. (2014), "Developing capability of public sector procurement in Ghana: An assessment of the road subsector client", In Proceedings of Construction Research Congress 2014, 19-21 May 2014, Atlanta, Georgia, USA. American Society of Civil Engineers.

Adewole, A. (2014), "Governance reform and the challenge of implementing public procurement law regime across Nigerian state and local governments", International Journal of Public Administration and Management Research (IJPAMR), Vol. 2 No. 4, pp. 25-32.

AfDB (2013), "The Infrastructure Action Plan for Nigeria: Closing the Infrastructure Gap and Accelerating Economic Transformation: Summary Report", AfDB, available at: http://www.afdb.org/fileadmin/uploads/afdb/Documents/Project-andOperations/An_Infrastructure_Action_Plan_for_Nigeria_-

Closing_the_Infrastructure_Gap_and_Accelerating_Economic_Transformation.p $\overline{d f}$ (Accessed 1 March 2016).

Agu, C. and Onodugo, V. A. (2009), "Infrastructure services decentralisation for poverty reduction: Nigerian states", Journal of Infrastructure Development, Vol.1 No. 2, pp. 153-178.

Ahadzie, D. K., Proverbs, D. G., and Olomolaiye, P.O. (2008), "Critical success criteria for mass house building projects in developing countries", International Journal of Project Management, Vol. 26, No. 6, pp. 675-687.

Ahadzie, D. K., Proverbs, D. G., Olomolaiye, P. O. and Ankrah, N. (2009), "Towards developing competency-based measures for project managers in mass house building projects in developing countries", Construction Management and Economics, Vol.27 No. 1, pp. 89-102.

Appiah, R. E. (2011), "Building relevant skills for public procurement", E-Procurement Bulletin, Vol.2 No.1, pp. 1-6.

Basheka, B. C. (2010), "Public procurement skills requirement framework for local government system in Uganda: Perception from professionals", IPPU, available online at http://www.ippu.or.ug (accessed 1 March 2016).

BPP (2016), "Bureau of Public Procurement (BPP) Nigeria", available at: http://www.bpp.gov.ng/ (accessed 12 March 2016). 
Carr, A. S. and Smeltzer, L. R. (2000), "An empirical study of the relationships among purchasing skills and strategic purchasing, financial performance and supplier responsiveness", Journal of Supply Chain Management, Vol. 36 No. 3, pp. 40-54.

Creswell, J.W. (2009), Research Design: Qualitative, Quantitative and Mixed Method Approaches, $3^{\text {rd }}$ ed, Sage, California.

Dainty, A.R., Cheng, M.I. and Moore, D.R. (2004), "A competency-based performance model for construction project managers", Construction Management and Economics, Vol. 22 No. 8, pp.877-886.

Fellows, R. and Liu, A. (2008), Research methods for construction, Blackwell Publishing, West Sussex.

Foster, V. and Pushak, N (2011), "Nigeria's infrastructure: A continental perspective: Africa Infrastructure Country Diagnostic (AICD). Country Report", The International Bank for Reconstruction and Development - The World Bank.

Giunipero, L., Handfield, R.B. and Eltantawy, R. (2006), "Supply management's evolution: Key skill sets for the supply manager of the future", International Journal of Production and Operations Management, Vol. 26 No. 7, pp. 822-844.

Giunipero, L.C. and Pearcy, D.H. (2000), "World class purchasing skills: An empirical investigation", Journal of Supply Chain Management, Vol. 36 No. 4, pp. 4-13.

Glass, J. (2011), "Briefing: Responsible sourcing of construction products", Proceedings of The Institution of Civil Engineers-Engineering Sustainability, Vol.164 No.3, pp.167-170.

Global Construction Perspectives and Oxford Economics (2013), "Global construction 2025. Global Construction Perspectives and Oxford Economics", available at http://www.globalconstruction2025.com/ (accessed 30 July 2015).

Kaduna State Government (2013), "State development plan 2014-2018". Kaduna State Government, available online at http://www.sparcnigeria.com/RC/files/1.1.9_Kaduna_Development_Plan_2014_2018.pdf. (accessed 05 October 2016).

Kolchin, M. and Giunipero, L. (1993), "Purchasing education and training:

Requirements and Resources", Arizona: Center for Advanced Purchasing Studies.

Kwofie, T.E., Amos-Abanyie, S., and Afram, S.O. (2016), "Principal component analysis of professional competencies of architects in the Ghanaian construction industry". Engineering, Construction and Architectural Management, Vol 23 No. 5, pp.571-587.

Lamptey, J. L. and Elle, L. (2000), "Evaluation Ghana Joint evaluation of the road subsector programme 1996-2000", available online at www2.jica.go.jp/ja/evaluation/pdf/2000_GH-P12_4_f.pdf (accessed 01 March 2016).

Mensah, S. and Ameyaw, C. (2012), "Sustainable procurement: the challenges of practice in the Ghanaian construction industry", In Laryea, S., Agyepong, S.A., Leiringer, R. and Hughes, W. (Eds) Proceedings 4th West Africa Built Environment Research (WABER) Conference,24-26 July 2012, Abuja, Nigeria, 871-880.

MOJ (2012), "Ministry of Justice - Procurement Competence Frameworks", MOJ, available at http://www.justice.gov.uk/downloads/jobs/competencyframework/procurement-competencies.doc (accessed 1 March 2016).

NZGP (2014), "Procurement -Training needs self-assessment tool", available at: http://www.business.govt.nz/procurement/pdf-library/agencies/developingcapability/training-needs-analysis-tool-2003-1(accessed 1 March 2016). 
OECD and World Bank (2004), "Good practice paper on procurement capacity development", The OECD Development Assistance Committee (DAC) - World Bank 3rd joint round table on strengthening procurement capacities in 24 developing countries, 30 November - 2 December 2004, Johannesburg, South Africa.

OECD and World Bank (2004), "Good practice paper on procurement capacity development", The OECD Development Assistance Committee (DAC) - World Bank 3rd joint round table on strengthening procurement capacities in 24 developing countries, 30 November - 2 December 2004, Johannesburg, South Africa.

OGC (2007), "Sustainability: Achieving Excellence in Construction Procurement Guide 11", HM Treasury, London.

OGC (2008), "An Introduction to Public Procurement. Office of Government Commerce", available at:

http://webarchive.nationalarchives.gov.uk/20110601212617/http:/www.ogc.gov.uk/ documents/Introduction_to_Public_Procurement.pdf (accessed 1 March 2016).

Oyo State Government (2010), "Strategic health development plan (2010-2015)", Oyo State Government, available at http://www.mamaye.org.ng/sites/default/files/evidence/Oyo\%20SSHDP\%2005.01. 11.pdf (accessed 28 January 2017).

Presidential Infrastructure Coordinating Commission (2012), "A summary of the South African national infrastructure plan", Presidential Infrastructure Coordinating Commission, available at http://www.gov.za/issues/national-infrastructure-plan. (accessed 22 February 2017).

Stephen, P. and Triraganon, R. (2009), "Strengthening Voices for Better Choices: A capacity needs assessment process", Gland, Switzerland: IUCN.

Tassabehji, R., and Moorhouse, A. (2008), "The changing role of procurement: Developing professional effectiveness", Journal of Purchasing and Supply Mana gement, Vol.14 No.1, pp. 55-68.

UNDP (2006), "Procurement Capacity Assessment User's Guide", UNDP Capacity Development Group Bureau for Development Policy.

UNDP (2007), "Capacity Assessment Practice Note. UNDP", available at http://www.unpcdc.org/media/8651/pn_capacity_development.pdf (accessed 1 March 2016).

UNDP (2010), "Public procurement capacity development guide", UNDP, available at from:

http://unpcdc.org/media/140954/procurement\%20capacity\%20assessment\%20gui de.pdf (accessed 1 March 2016).

United Nations Economic and Social Council (2016), "Progress towards the Sustainable Development Goals - Report of the Secretary-General", United Nations Economic and Social Council, available at https://unstats.un.org/sdgs/files/report/2016/secretary-general-sdg-report-2016-EN.pdf. (accessed 23 March 2017).

Upstill-Goddard, J. D., Glass, J., Dainty, A. R. J., Nicholson, I. (2015), "Analysis of responsible sourcing performance in BES 6001 certificates", Proceedings of the Institution of Civil Engineers: Engineering Sustainability, Vol.168 No. 2, pp.71-81.

Veitch, C. (2014), "Infrastructure Industry in Nigeria", Who owns Who (Pty), South Africa. Siccode 502, available at: http://www.whoownswhom.co.za/public/sasector/report_content/Pages\%20from\% 20502\%20-\%20The\%20Infrastructure\%20Industry\%20Nigeria\%20\%20March\%202016\%20-\%20Contents.pdf. (accessed 03 April 2016) 
World Bank (1995), "Restoring urban Nigeria a strategy for restoring urban infrastructure and services in Nigeria". Report No. 45557. Washington, DC: World Bank, available online http://documents.worldbank.org/curated/en/1995/12/10735837/restoring-urbannigeria-strategy-restoring-urban-infrastructure-services-nigeria (accessed 01 March 2016).

World Bank (2000), "Nigeria: Country Procurement Assessment Report (CPAR)", Vol 1. Summary of findings and recommendations. Nigeria Country Department, World Bank, Africa Region, available

at: http://documents.worldbank.org/curated/en/2000/06/1121258/nigeria-countryprocurement-assessment-report-cpar (accessed 1 March 2016).

World Bank (2003), "Ghana: Country Procurement Assessment Report (CPAR)", Vol 1. Executive Summary. Washington, DC: World Bank, available online at https://openknowledge.worldbank.org/handle/10986/15638 (accessed 1 March 2016).

World Bank (2013), "Nigeria Value Chain Analysis Study - A Study of Selected MDA's. World Bank Africa", Report Number ACS 1666, World Bank, Washington DC. 

Table 1: Skills for Procurement

Literature Sources

\begin{tabular}{|c|c|c|c|c|c|c|c|c|c|c|c|c|c|}
\hline & 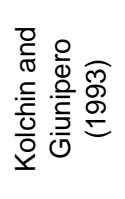 & 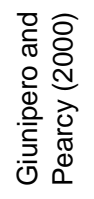 & 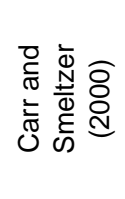 & 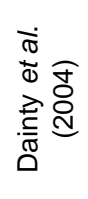 & 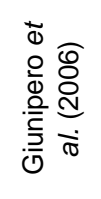 & 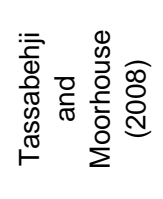 & 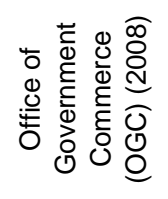 & $\begin{array}{l}\frac{\pi}{\pi} \\
\frac{\pi}{0} \\
\frac{0}{N} \\
\frac{\pi}{0} \\
\frac{\pi}{d} \\
\frac{\pi}{<}\end{array}$ & 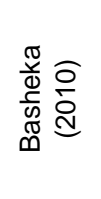 & 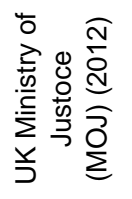 & 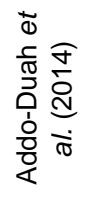 & 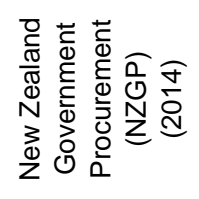 & 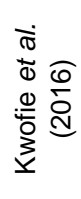 \\
\hline Communication (oral/written) & $\sqrt{ }$ & $\sqrt{ }$ & $\sqrt{ }$ & $\sqrt{ }$ & $\sqrt{ }$ & $\sqrt{ }$ & & $\sqrt{ }$ & $\sqrt{ }$ & & $\sqrt{ }$ & $\sqrt{ }$ & $\sqrt{ }$ \\
\hline Computing/ICT & $\sqrt{ }$ & $\sqrt{ }$ & $\sqrt{ }$ & & $\sqrt{ }$ & $\sqrt{ }$ & & & $\sqrt{ }$ & $\sqrt{ }$ & $\sqrt{ }$ & $\sqrt{ }$ & \\
\hline Conflict resolution and management & $\sqrt{ }$ & $\sqrt{ }$ & $\sqrt{ }$ & $\sqrt{ }$ & & $\sqrt{ }$ & & $\sqrt{ }$ & & $\sqrt{ }$ & $\sqrt{ }$ & & $\sqrt{ }$ \\
\hline Whole life costing and financial analysis & & & & $\sqrt{ }$ & & & $\sqrt{ }$ & & $\sqrt{ }$ & & & & \\
\hline Cost management and accounting compliance & $\sqrt{ }$ & & $\sqrt{ }$ & & $\sqrt{ }$ & $\sqrt{ }$ & $\sqrt{ }$ & $\sqrt{ }$ & $\sqrt{ }$ & $\sqrt{ }$ & $\sqrt{ }$ & $\sqrt{ }$ & \\
\hline Leadership & $\sqrt{ }$ & $\sqrt{ }$ & & $\sqrt{ }$ & $\sqrt{ }$ & $\sqrt{ }$ & $\sqrt{ }$ & & & $\sqrt{ }$ & $\sqrt{ }$ & $\sqrt{ }$ & \\
\hline Negotiation & $\sqrt{ }$ & $\sqrt{ }$ & $\sqrt{ }$ & $\sqrt{ }$ & $\sqrt{ }$ & $\sqrt{ }$ & $\sqrt{ }$ & & $\sqrt{ }$ & & $\sqrt{ }$ & $\sqrt{ }$ & $\sqrt{ }$ \\
\hline Proposal evaluation & & $\sqrt{ }$ & & & $\sqrt{ }$ & $\sqrt{ }$ & $\sqrt{ }$ & & & & $\sqrt{ }$ & $\sqrt{ }$ & \\
\hline Quality management & $\sqrt{ }$ & & $\sqrt{ }$ & $\sqrt{ }$ & & $\sqrt{ }$ & $\sqrt{ }$ & $\sqrt{ }$ & & & $\sqrt{ }$ & $\sqrt{ }$ & \\
\hline Relationship management & $\sqrt{ }$ & $\sqrt{ }$ & $\sqrt{ }$ & & $\sqrt{ }$ & $\sqrt{ }$ & $\sqrt{ }$ & $\sqrt{ }$ & $\sqrt{ }$ & $\sqrt{ }$ & $\sqrt{ }$ & $\sqrt{ }$ & \\
\hline Risk management & $\sqrt{ }$ & $\sqrt{ }$ & & & $\sqrt{ }$ & $\sqrt{ }$ & $\sqrt{ }$ & $\sqrt{ }$ & $\sqrt{ }$ & & $\sqrt{ }$ & & $\sqrt{ }$ \\
\hline Responsible sourcing/Green purchasing/Green procurement & $\sqrt{ }$ & & & & & & $\sqrt{ }$ & & $\sqrt{ }$ & $\sqrt{ }$ & & & $\sqrt{ }$ \\
\hline Strategic planning & $\sqrt{ }$ & $\sqrt{ }$ & $\sqrt{ }$ & $\sqrt{ }$ & $\sqrt{ }$ & $\sqrt{ }$ & $\sqrt{ }$ & & $\sqrt{ }$ & $\sqrt{ }$ & $\sqrt{ }$ & $\sqrt{ }$ & \\
\hline Variation/Change management & $\sqrt{ }$ & $\sqrt{ }$ & & & & $\sqrt{ }$ & & & & & $\sqrt{ }$ & & \\
\hline Time management & & & $\sqrt{ }$ & & & $\sqrt{ }$ & & $\sqrt{ }$ & $\sqrt{ }$ & & & $\sqrt{ }$ & \\
\hline Application of ethics guidelines in procurement & & & & & & & $\sqrt{ }$ & & $\sqrt{ }$ & & & $\sqrt{ }$ & \\
\hline
\end{tabular}


Procurement planning

Decision making

Entrepreneurship

Creative thinking

Problem solving

Stakeholder management

Application of national procurement law and procedures

Application of international procurement law and procedures

Application of modern integrated procurement procedures

Contract management and enforcement

Marketing

Research and development

E-procurement

Sustainable design

Data (quantitative and qualitative) analysis

Team building

Market analysis and forecasting

Business case development

Project scope definition

Project strategy development/organisational governance

Tendering 
Project monitoring and auditing/evaluation

Application of diversity and equal opportunities procedures

Application of corporate social responsibility procedures

Cross cultural awareness

Stress management

Environmental management

Health and safety management

Value engineering 
Table 2: Methods for Skills or Competency Development

\section{Methods}

Further / Higher academic degree courses

Apprenticeships

Self-learning through manuals, academic or professional journals

Exchange visits and study tours

On-the-job-training

Short continuous professional development (CPD) courses

Coaching, mentoring and shadowing

Networking and sharing ideas with other professionals

Work team retreats

Conferences and workshop attendance

More job responsibility

Job rotation or secondment

Internships and placements

Distant / Online Learning

In-house training courses

Sources: Giunipero et al. (2006), Stephen and Triraganon (2009), Basheka (2010) and UNDP $(2006 ; 2007 ; 2010)$ 
Table 3: Important Skills for Infrastructure Procurement

\begin{tabular}{|c|c|c|c|c|c|c|c|c|c|c|c|c|}
\hline \multirow{3}{*}{ Skills } & \multirow{3}{*}{$\mathrm{N}$} & \multirow{3}{*}{ Mean } & \multirow{3}{*}{$\begin{array}{l}\text { Rank } \\
\text { by } \\
\text { Mean }\end{array}$} & \multirow{3}{*}{$\begin{array}{l}\text { Std. } \\
\text { Dev. }\end{array}$} & \multirow{3}{*}{$\begin{array}{l}\text { Std. } \\
\text { Error } \\
\text { Mean }\end{array}$} & \multicolumn{7}{|c|}{ One-Sample T-test (Test Value $=3.5)$} \\
\hline & & & & & & \multirow[t]{2}{*}{$\mathrm{t}$} & \multirow[t]{2}{*}{ df } & \multirow[t]{2}{*}{$\begin{array}{l}\text { Sig. }(2- \\
\text { tailed) }\end{array}$} & \multirow[t]{2}{*}{$\begin{array}{l}\text { Sig. }(1- \\
\text { tailed) }\end{array}$} & \multirow[t]{2}{*}{ Mean Diff. } & \multicolumn{2}{|c|}{$\begin{array}{l}95 \% \text { Confidence } \\
\text { Interval of the } \\
\text { Difference }\end{array}$} \\
\hline & & & & & & & & & & & Lower & Upper \\
\hline Communication (oral/written) & 288 & 4.319 & 1 & 0.889 & 0.052 & 15.650 & 287 & 0.000 & 0.000 & 0.819 & 0.716 & 0.923 \\
\hline Quality management & 288 & 4.125 & 2 & 0.821 & 0.048 & 12.917 & 287 & 0.000 & 0.000 & 0.625 & 0.530 & 0.720 \\
\hline Project monitoring and auditing/evaluation & 288 & 4.118 & 3 & 0.883 & 0.052 & 11.873 & 287 & 0.000 & 0.000 & 0.618 & 0.516 & 0.721 \\
\hline Team building & 287 & 4.084 & 4 & 0.753 & 0.044 & 13.137 & 286 & 0.000 & 0.000 & 0.584 & 0.496 & 0.671 \\
\hline Decision making & 286 & 4.070 & 5 & 0.880 & 0.052 & 10.955 & 285 & 0.000 & 0.000 & 0.570 & 0.468 & 0.672 \\
\hline Leadership & 287 & 4.059 & 6 & 0.857 & 0.051 & 11.056 & 286 & 0.000 & 0.000 & 0.559 & 0.460 & 0.659 \\
\hline Value engineering & 288 & 4.052 & 7 & 0.956 & 0.056 & 9.802 & 287 & 0.000 & 0.000 & 0.552 & 0.441 & 0.663 \\
\hline Health and safety management & 287 & 4.045 & 8 & 0.886 & 0.052 & 10.429 & 286 & 0.000 & 0.000 & 0.545 & 0.442 & 0.648 \\
\hline Computing/ICT & 287 & 4.031 & 9 & 0.947 & 0.056 & 9.501 & 286 & 0.000 & 0.000 & 0.531 & 0.421 & 0.641 \\
\hline Problem solving & 287 & 4.031 & 9 & 0.866 & 0.051 & 10.389 & 286 & 0.000 & 0.000 & 0.531 & 0.431 & 0.632 \\
\hline Time management & 288 & 4.024 & 11 & 0.841 & 0.050 & 10.584 & 287 & 0.000 & 0.000 & 0.524 & 0.427 & 0.622 \\
\hline Procurement planning & 287 & 4.014 & 12 & 0.924 & 0.055 & 9.427 & 286 & 0.000 & 0.000 & 0.514 & 0.407 & 0.621 \\
\hline Data (quantitative and qualitative) analysis & 288 & 3.993 & 13 & 0.835 & 0.049 & 10.024 & 287 & 0.000 & 0.000 & 0.493 & 0.396 & 0.590 \\
\hline Tendering & 287 & 3.986 & 14 & 0.823 & 0.049 & 9.999 & 286 & 0.000 & 0.000 & 0.486 & 0.390 & 0.582 \\
\hline Proposal evaluation & 286 & 3.983 & 15 & 0.880 & 0.052 & 9.268 & 285 & 0.000 & 0.000 & 0.483 & 0.380 & 0.585 \\
\hline Relationship management & 287 & 3.955 & 16 & 0.850 & 0.050 & 9.067 & 286 & 0.000 & 0.000 & 0.455 & 0.356 & 0.553 \\
\hline Strategic planning & 288 & 3.955 & 16 & 0.900 & 0.053 & 8.578 & 287 & 0.000 & 0.000 & 0.455 & 0.350 & 0.559 \\
\hline Creative thinking & 287 & 3.937 & 18 & 0.977 & 0.058 & 7.584 & 286 & 0.000 & 0.000 & 0.437 & 0.324 & 0.551 \\
\hline Sustainable design & 288 & 3.903 & 19 & 0.878 & 0.052 & 7.785 & 287 & 0.000 & 0.000 & 0.403 & 0.301 & 0.505 \\
\hline Cost management and accounting compliance & 288 & 3.896 & 20 & 0.924 & 0.054 & 7.272 & 287 & 0.000 & 0.000 & 0.396 & 0.289 & 0.503 \\
\hline Contract management and enforcement & 287 & 3.889 & 21 & 0.890 & 0.053 & 7.397 & 286 & 0.000 & 0.000 & 0.389 & 0.285 & 0.492 \\
\hline $\begin{array}{l}\text { Application of national procurement law and } \\
\text { procedures }\end{array}$ & 288 & 3.878 & 22 & 0.946 & 0.056 & 6.791 & 287 & 0.000 & 0.000 & 0.378 & 0.269 & 0.488 \\
\hline
\end{tabular}


Market analysis and forecasting

Project scope definition

Negotiation

Project strategy development/organisational governance

Application of ethics guidelines in procurement

Environmental management

Research and development

Variation/Change management

Application of modern integrated procurement procedures

Whole life costing and financial analysis

Conflict resolution and managemen

Stakeholder management

Application of diversity and equal opportunities procedures

Marketing

E-procurement

Entrepreneurship

Business case development

Risk management

Stress management

Application of corporate social responsibility

Application of international procurement law and

procedures

Responsible sourcing/Green purchasing/Green

procurement

\begin{tabular}{|c|c|c|c|c|c|c|c|c|c|c|c|}
\hline 287 & 3.875 & 23 & 0.884 & 0.052 & 7.178 & 286 & 0.000 & 0.000 & 0.375 & 0.272 & 0.477 \\
\hline 287 & 3.871 & 24 & 0.878 & 0.052 & 7.164 & 286 & 0.000 & 0.000 & 0.371 & 0.269 & 0.473 \\
\hline 287 & 3.861 & 25 & 0.917 & 0.054 & 6.663 & 286 & 0.000 & 0.000 & 0.361 & 0.254 & 0.467 \\
\hline 287 & 3.854 & 26 & 0.889 & 0.052 & 6.742 & 286 & 0.000 & 0.000 & 0.354 & 0.250 & 0.457 \\
\hline 287 & 3.840 & 27 & 1.046 & 0.062 & 5.505 & 286 & 0.000 & 0.000 & 0.340 & 0.218 & 0.461 \\
\hline 288 & 3.837 & 28 & 0.902 & 0.053 & 6.339 & 287 & 0.000 & 0.000 & 0.337 & 0.232 & 0.441 \\
\hline 287 & 3.801 & 29 & 0.960 & 0.057 & 5.318 & 286 & 0.000 & 0.000 & 0.301 & 0.190 & 0.413 \\
\hline 287 & 3.780 & 30 & 0.830 & 0.049 & 5.723 & 286 & 0.000 & 0.000 & 0.280 & 0.184 & 0.377 \\
\hline 288 & 3.771 & 31 & 0.905 & 0.053 & 5.081 & 287 & 0.000 & 0.000 & 0.271 & 0.166 & 0.376 \\
\hline 287 & 3.749 & 32 & 0.912 & 0.054 & 4.627 & 286 & 0.000 & 0.000 & 0.249 & 0.143 & 0.355 \\
\hline 287 & 3.746 & 33 & 0.983 & 0.058 & 4.233 & 286 & 0.000 & 0.000 & 0.246 & 0.131 & 0.360 \\
\hline 288 & 3.708 & 34 & 0.973 & 0.057 & 3.635 & 287 & 0.000 & 0.000 & 0.208 & 0.096 & 0.321 \\
\hline 287 & 3.707 & 35 & 0.988 & 0.058 & 3.553 & 286 & 0.000 & 0.000 & 0.207 & 0.092 & 0.322 \\
\hline 287 & 3.659 & 36 & 0.909 & 0.054 & 2.953 & 286 & 0.003 & 0.002 & 0.159 & 0.053 & 0.264 \\
\hline 288 & 3.646 & 37 & 1.012 & 0.060 & 2.446 & 287 & 0.015 & 0.008 & 0.146 & 0.028 & 0.263 \\
\hline 287 & 3.645 & 38 & 1.003 & 0.059 & 2.442 & 286 & 0.015 & 0.008 & 0.145 & 0.028 & 0.261 \\
\hline 286 & 3.643 & 39 & 0.954 & 0.056 & 2.540 & 285 & 0.012 & 0.006 & 0.143 & 0.032 & 0.254 \\
\hline 287 & 3.638 & 40 & 0.990 & 0.058 & 2.355 & 286 & 0.019 & 0.010 & 0.138 & 0.023 & 0.253 \\
\hline 287 & 3.606 & 41 & 0.987 & 0.058 & 1.824 & 286 & 0.069 & 0.035 & 0.106 & -0.008 & 0.221 \\
\hline 287 & 3.599 & 42 & 0.980 & 0.058 & 1.716 & 286 & 0.087 & 0.044 & 0.099 & -0.015 & 0.213 \\
\hline 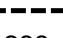 & י---- & & ----- & $=-$ & ---- & --1 & ---- & ----- & 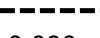 & ----- & ---- \\
\hline 288 & 3.590 & 43 & 0.976 & 0.058 & 1.569 & 287 & 0.118 & 0.059 & 0.090 & -0.023 & 0.204 \\
\hline 287 & 3.502 & 44 & 0.971 & 0.057 & 0.030 & 286 & 0.976 & 0.488 & 0.002 & -0.111 & 0.115 \\
\hline 287 & 3.477 & 45 & 1.013 & 0.060 & -0.379 & 286 & 0.705 & 0.353 & -0.023 & -0.140 & 0.095 \\
\hline
\end{tabular}

Notes: Scale: 1 = strongly disagree; 2 = disagree; 3 = neutral; 4 = agree; 5 = strongly agree

For skills below the dash line, Mean is not significantly greater than 3.5 
Table 4: Skills Development Needs for Infrastructure Procurement

\begin{tabular}{|c|c|c|c|c|c|c|c|c|c|c|c|c|}
\hline \multirow{3}{*}{ Skills } & \multirow{3}{*}{$\mathrm{N}$} & \multirow{3}{*}{ Mean } & \multirow{3}{*}{$\begin{array}{l}\text { Rank by } \\
\text { Mean }\end{array}$} & \multirow{3}{*}{$\begin{array}{l}\text { Std. } \\
\text { Dev. }\end{array}$} & \multirow{3}{*}{$\begin{array}{l}\text { Std. Error } \\
\text { Mean }\end{array}$} & \multicolumn{7}{|c|}{ One-Sample T-tes $($ Test Value $=3.5)$} \\
\hline & & & & & & \multirow{2}{*}{$\mathrm{t}$} & \multirow{2}{*}{$\mathrm{df}$} & \multirow{2}{*}{$\begin{array}{l}\text { Sig. }(2- \\
\text { tailed) }\end{array}$} & \multirow{2}{*}{$\begin{array}{l}\text { Sig. (1- } \\
\text { tailed) }\end{array}$} & \multirow{2}{*}{$\begin{array}{l}\text { Mean } \\
\text { Diff. }\end{array}$} & \multicolumn{2}{|c|}{$\begin{array}{l}\text { 95\% Confidence Interva } \\
\text { of the Difference }\end{array}$} \\
\hline & & & & & & & & & & & Upper & Lower \\
\hline Computing/ICT & 287 & 4.139 & 1 & 0.917 & 0.054 & 11.814 & 286 & 0.000 & 0.000 & 0.639 & 0.746 & 0.533 \\
\hline Problem solving & 286 & 4.080 & 2 & 3.181 & 0.188 & 3.086 & 285 & 0.002 & 0.001 & 0.580 & 0.951 & 0.210 \\
\hline Communication (oral/written) & 287 & 4.066 & 3 & 1.041 & 0.061 & 9.217 & 286 & 0.000 & 0.000 & 0.566 & 0.687 & 0.445 \\
\hline Decision making & 286 & 4.021 & 4 & 0.933 & 0.055 & 9.447 & 285 & 0.000 & 0.000 & 0.521 & 0.630 & 0.412 \\
\hline Health and safety management & 287 & 3.976 & 5 & 0.980 & 0.058 & 8.219 & 286 & 0.000 & 0.000 & 0.476 & 0.590 & 0.362 \\
\hline Quality management & 287 & 3.972 & 6 & 0.885 & 0.052 & 9.042 & 286 & 0.000 & 0.000 & 0.472 & 0.575 & 0.369 \\
\hline Relationship management & 286 & 3.923 & 7 & 3.119 & 0.184 & 2.294 & 285 & 0.023 & 0.011 & 0.423 & 0.786 & 0.060 \\
\hline Team building & 287 & 3.909 & 8 & 0.945 & 0.056 & 7.336 & 286 & 0.000 & 0.000 & 0.409 & 0.519 & 0.300 \\
\hline Project monitoring and auditing/evaluation & 286 & 3.906 & 9 & 0.981 & 0.058 & 6.990 & 285 & 0.000 & 0.000 & 0.406 & 0.520 & 0.291 \\
\hline Time management & 287 & 3.902 & 10 & 0.952 & 0.056 & 7.161 & 286 & 0.000 & 0.000 & 0.402 & 0.513 & 0.292 \\
\hline Procurement planning & 287 & 3.892 & 11 & 0.938 & 0.055 & 7.079 & 286 & 0.000 & 0.000 & 0.392 & 0.501 & 0.283 \\
\hline Strategic planning & 286 & 3.892 & 11 & 0.973 & 0.058 & 6.809 & 285 & 0.000 & 0.000 & 0.392 & 0.505 & 0.278 \\
\hline Leadership & 287 & 3.885 & 13 & 0.952 & 0.056 & 6.851 & 286 & 0.000 & 0.000 & 0.385 & 0.496 & 0.274 \\
\hline Creative thinking & 286 & 3.864 & 14 & 0.958 & 0.057 & 6.418 & 285 & 0.000 & 0.000 & 0.364 & 0.475 & 0.252 \\
\hline Value engineering & 287 & 3.850 & 15 & 1.052 & 0.062 & 5.639 & 286 & 0.000 & 0.000 & 0.350 & 0.472 & 0.228 \\
\hline Data (quantitative and qualitative) analysis & 287 & 3.847 & 16 & 0.922 & 0.054 & 6.368 & 286 & 0.000 & 0.000 & 0.347 & 0.454 & 0.240 \\
\hline Proposal evaluation & 287 & 3.833 & 17 & 0.908 & 0.054 & 6.206 & 286 & 0.000 & 0.000 & 0.333 & 0.438 & 0.227 \\
\hline Contract management and enforcement & 287 & 3.819 & 18 & 1.039 & 0.061 & 5.200 & 286 & 0.000 & 0.000 & 0.319 & 0.439 & 0.198 \\
\hline Environmental management & 287 & 3.819 & 18 & 0.987 & 0.058 & 5.473 & 286 & 0.000 & 0.000 & 0.319 & 0.433 & 0.204 \\
\hline Conflict resolution and management & 286 & 3.818 & 20 & 1.023 & 0.061 & 5.257 & 285 & 0.000 & 0.000 & 0.318 & 0.437 & 0.199 \\
\hline Research and development & 286 & 3.794 & 21 & 1.003 & 0.059 & 4.951 & 285 & 0.000 & 0.000 & 0.294 & 0.410 & 0.177 \\
\hline Tendering & 286 & 3.762 & 22 & 1.029 & 0.061 & 4.309 & 285 & 0.000 & 0.000 & 0.262 & 0.382 & 0.142 \\
\hline Market analysis and forecasting & 286 & 3.752 & 23 & 0.924 & 0.055 & 4.607 & 285 & 0.000 & 0.000 & 0.252 & 0.359 & 0.144 \\
\hline Application of national procurement law and procedures & 287 & 3.739 & 24 & 1.076 & 0.064 & 3.756 & 286 & 0.000 & 0.000 & 0.239 & 0.364 & 0.114 \\
\hline
\end{tabular}




\begin{tabular}{|c|c|c|c|c|c|c|c|c|c|c|c|c|}
\hline Sustainable design & 286 & 3.727 & 25 & 1.013 & 0.060 & 3.792 & 285 & 0.000 & 0.000 & 0.227 & 0.345 & 0.109 \\
\hline Cost management and accounting compliance & 287 & 3.721 & 26 & 0.996 & 0.059 & 3.763 & 286 & 0.000 & 0.000 & 0.221 & 0.337 & 0.106 \\
\hline Project strategy development/organisational governance & 286 & 3.710 & 27 & 0.986 & 0.058 & 3.599 & 285 & 0.000 & 0.000 & 0.210 & 0.325 & 0.095 \\
\hline Application of ethics guidelines in procurement & 285 & 3.698 & 28 & 1.024 & 0.061 & 3.267 & 284 & 0.001 & 0.001 & 0.198 & 0.318 & 0.079 \\
\hline Stakeholder management & 285 & 3.691 & 29 & 1.036 & 0.061 & 3.116 & 284 & 0.002 & 0.001 & 0.191 & 0.312 & 0.070 \\
\hline Project scope definition & 285 & 3.691 & 29 & 1.026 & 0.061 & 3.147 & 284 & 0.002 & 0.001 & 0.191 & 0.311 & 0.072 \\
\hline $\begin{array}{l}\text { Application of modern integrated procurement } \\
\text { procedures }\end{array}$ & 285 & 3.681 & 31 & 1.055 & 0.062 & 2.892 & 284 & 0.004 & 0.002 & 0.181 & 0.304 & 0.058 \\
\hline Entrepreneurship & 287 & 3.659 & 32 & 1.072 & 0.063 & 2.506 & 286 & 0.013 & 0.006 & 0.159 & 0.283 & 0.034 \\
\hline Risk management & 287 & 3.655 & 33 & 1.022 & 0.060 & 2.570 & 286 & 0.011 & 0.005 & 0.155 & 0.274 & 0.036 \\
\hline Whole life costing and financial analysis & 287 & 3.631 & 34 & 0.991 & 0.058 & 2.234 & 286 & 0.026 & 0.013 & 0.131 & 0.246 & 0.016 \\
\hline Negotiation & 287 & 3.631 & 34 & 1.029 & 0.061 & 2.151 & 286 & 0.032 & 0.016 & 0.131 & 0.250 & 0.011 \\
\hline $\begin{array}{l}\text { Application of diversity and equal opportunities } \\
\text { procedures }\end{array}$ & 287 & 3.606 & 36 & 1.065 & 0.063 & 1.690 & 286 & 0.092 & 0.046 & 0.106 & 0.230 & -0.017 \\
\hline Marketing & 286 & 3.605 & 37 & 1.023 & 0.061 & 1.734 & 285 & 0.084 & 0.042 & 0.105 & 0.224 & -0.014 \\
\hline Variation/Change management & 286 & 3.594 & 38 & 0.935 & 0.055 & 1.708 & 285 & 0.089 & 0.044 & 0.094 & 0.203 & -0.014 \\
\hline E-procurement & 286 & 3.563 & 39 & 1.140 & 0.067 & 0.934 & 285 & 0.351 & 0.176 & 0.063 & 0.196 & -0.070 \\
\hline Stress management & 287 & 3.561 & 40 & 1.151 & 0.068 & 0.898 & 286 & 0.370 & 0.185 & 0.061 & 0.195 & -0.073 \\
\hline $\begin{array}{l}\text { Application of international procurement law and } \\
\text { procedures }\end{array}$ & 287 & 3.544 & 41 & 1.136 & 0.067 & 0.649 & 286 & 0.517 & 0.258 & 0.044 & 0.176 & -0.088 \\
\hline Application of corporate social responsibility procedures & 286 & 3.503 & 42 & 1.069 & 0.063 & 0.055 & 285 & 0.956 & 0.478 & 0.003 & 0.128 & -0.121 \\
\hline Cross cultural awareness & 287 & 3.425 & 43 & 1.094 & 0.065 & -1.160 & 286 & 0.247 & 0.123 & -0.075 & 0.052 & -0.202 \\
\hline $\begin{array}{l}\text { Responsible sourcing/Green purchasing/Green } \\
\text { procurement }\end{array}$ & 284 & 3.419 & 44 & 1.045 & 0.062 & -1.306 & 283 & 0.193 & 0.096 & -0.081 & 0.041 & -0.203 \\
\hline Business case development & 286 & 3.409 & 45 & 1.065 & 0.063 & -1.444 & 285 & 0.150 & 0.075 & -0.091 & 0.033 & -0.215 \\
\hline
\end{tabular}

Business case development 
Table 5: Differences in Perceived Infrastructure Procurement Skills Development Needs - By Type of Organisation

\begin{tabular}{|c|c|c|c|c|c|c|c|c|c|c|c|c|c|}
\hline \multirow{3}{*}{ Skills } & \multirow{3}{*}{ Organisation } & \multirow{3}{*}{$\mathrm{N}$} & \multirow{3}{*}{ Mean } & \multirow{3}{*}{$\begin{array}{l}\text { Std. } \\
\text { Dev. }\end{array}$} & \multirow{3}{*}{$\begin{array}{l}\text { Std. } \\
\text { Error } \\
\text { Mean }\end{array}$} & \multicolumn{8}{|c|}{ Independent Samples t-test } \\
\hline & & & & & & \multicolumn{3}{|c|}{ Levene's Test for Equality of Variances } & \multicolumn{5}{|c|}{ t-test for Equality of Means } \\
\hline & & & & & & $\begin{array}{l}\text { Equality of } \\
\text { Variances }\end{array}$ & $\mathrm{F}$ & Sig. & $t$ & df & $\begin{array}{l}\text { Sig. (2- } \\
\text { tailed) }\end{array}$ & Mean Diff. & $\begin{array}{l}\text { Std. Error } \\
\text { Diff. }\end{array}$ \\
\hline Proposal evaluation & $\begin{array}{l}\text { Local government } \\
\text { State government }\end{array}$ & $\begin{array}{l}150 \\
137\end{array}$ & $\begin{array}{l}3.627 \\
4.058\end{array}$ & $\begin{array}{l}0.909 \\
0.855\end{array}$ & $\begin{array}{l}0.074 \\
0.073\end{array}$ & $\begin{array}{l}\text { Equal variances } \\
\text { assumed } \\
\text { Equal variances } \\
\text { not assumed }\end{array}$ & 7.145 & 0.008 & $\begin{array}{l}-4.133 \\
-4.145\end{array}$ & $\begin{array}{l}285.000 \\
284.737\end{array}$ & $\begin{array}{l}0.000 \\
0.000\end{array}$ & $\begin{array}{l}-0.432 \\
-0.432\end{array}$ & $\begin{array}{l}0.104 \\
0.104\end{array}$ \\
\hline Risk management & $\begin{array}{l}\text { Local government } \\
\text { State government }\end{array}$ & $\begin{array}{l}150 \\
137\end{array}$ & $\begin{array}{l}3.487 \\
3.839\end{array}$ & $\begin{array}{l}1.041 \\
0.972\end{array}$ & $\begin{array}{l}0.085 \\
0.083\end{array}$ & $\begin{array}{l}\text { Equal variances } \\
\text { assumed } \\
\text { Equal variances } \\
\text { not assumed }\end{array}$ & 3.668 & 0.056 & $\begin{array}{l}-2.959 \\
-2.969\end{array}$ & $\begin{array}{l}285.000 \\
284.859\end{array}$ & $\begin{array}{l}0.003 \\
0.003\end{array}$ & $\begin{array}{l}-0.353 \\
-0.353\end{array}$ & $\begin{array}{l}0.119 \\
0.119\end{array}$ \\
\hline $\begin{array}{l}\text { Responsible } \\
\text { sourcing/Green } \\
\text { purchasing/Green } \\
\text { procurement }\end{array}$ & $\begin{array}{l}\text { Local government } \\
\text { State government }\end{array}$ & $\begin{array}{l}149 \\
135\end{array}$ & $\begin{array}{l}3.235 \\
3.622\end{array}$ & $\begin{array}{l}1.042 \\
1.014\end{array}$ & $\begin{array}{l}0.085 \\
0.087\end{array}$ & $\begin{array}{l}\text { Equal variances } \\
\text { assumed } \\
\text { Equal variances } \\
\text { not assumed }\end{array}$ & 0.018 & 0.893 & $\begin{array}{l}-3.168 \\
-3.173\end{array}$ & $\begin{array}{l}282.000 \\
280.570\end{array}$ & $\begin{array}{l}0.002 \\
0.002\end{array}$ & $\begin{array}{l}-0.387 \\
-0.387\end{array}$ & $\begin{array}{l}0.122 \\
0.122\end{array}$ \\
\hline $\begin{array}{l}\text { Application of ethics } \\
\text { guidelines in } \\
\text { procurement }\end{array}$ & $\begin{array}{l}\text { Local government } \\
\text { State government }\end{array}$ & $\begin{array}{l}150 \\
135\end{array}$ & $\begin{array}{l}3.493 \\
3.926\end{array}$ & $\begin{array}{l}1.035 \\
0.967\end{array}$ & $\begin{array}{l}0.084 \\
0.083\end{array}$ & $\begin{array}{l}\text { Equal variances } \\
\text { assumed } \\
\text { Equal variances } \\
\text { not assumed }\end{array}$ & 3.394 & 0.066 & $\begin{array}{l}-3.635 \\
-3.648\end{array}$ & $\begin{array}{l}283.000 \\
282.592\end{array}$ & $\begin{array}{l}0.000 \\
0.000\end{array}$ & $\begin{array}{l}-0.433 \\
-0.433\end{array}$ & $\begin{array}{l}0.119 \\
0.119\end{array}$ \\
\hline $\begin{array}{l}\text { Procurement } \\
\text { planning }\end{array}$ & $\begin{array}{l}\text { Local government } \\
\text { State government }\end{array}$ & $\begin{array}{r}150 \\
137\end{array}$ & $\begin{array}{l}3.760 \\
4.036\end{array}$ & $\begin{array}{l}0.974 \\
0.878\end{array}$ & $\begin{array}{l}0.080 \\
0.075\end{array}$ & $\begin{array}{l}\text { Equal variances } \\
\text { assumed } \\
\text { Equal variances } \\
\text { not assumed }\end{array}$ & 4.205 & 0.041 & $\begin{array}{l}-2.517 \\
-2.529\end{array}$ & $\begin{array}{l}285.000 \\
284.953\end{array}$ & $\begin{array}{l}0.012 \\
0.012\end{array}$ & $\begin{array}{l}-0.276 \\
-0.276\end{array}$ & $\begin{array}{l}0.110 \\
0.109\end{array}$ \\
\hline $\begin{array}{l}\text { Application of } \\
\text { national } \\
\text { procurement law } \\
\text { and procedures }\end{array}$ & $\begin{array}{l}\text { Local government } \\
\text { State government }\end{array}$ & $\begin{array}{l}150 \\
137\end{array}$ & $\begin{array}{l}3.560 \\
3.934\end{array}$ & $\begin{array}{l}1.096 \\
1.023\end{array}$ & $\begin{array}{l}0.089 \\
0.087\end{array}$ & $\begin{array}{l}\text { Equal variances } \\
\text { assumed } \\
\text { Equal variances } \\
\text { not assumed }\end{array}$ & 6.603 & 0.011 & $\begin{array}{l}-2.983 \\
-2.992\end{array}$ & $\begin{array}{l}285.000 \\
284.857\end{array}$ & $\begin{array}{l}0.003 \\
0.003\end{array}$ & $\begin{array}{l}-0.374 \\
-0.374\end{array}$ & $\begin{array}{l}0.125 \\
0.125\end{array}$ \\
\hline $\begin{array}{l}\text { Application of } \\
\text { modern integrated }\end{array}$ & Local government & 150 & 3.520 & 1.060 & 0.087 & $\begin{array}{l}\text { Equal variances } \\
\text { assumed }\end{array}$ & 3.900 & 0.049 & -2.742 & 283.000 & 0.006 & -0.339 & 0.124 \\
\hline
\end{tabular}




\begin{tabular}{|c|c|c|c|c|c|c|c|c|c|c|c|c|c|}
\hline $\begin{array}{l}\text { procurement } \\
\text { procedures }\end{array}$ & State government & 135 & 3.859 & 1.023 & 0.088 & $\begin{array}{l}\text { Equal variances } \\
\text { not assumed }\end{array}$ & & & -2.747 & 281.600 & 0.006 & -0.339 & 0.123 \\
\hline Marketing & $\begin{array}{l}\text { Local government } \\
\text { State government }\end{array}$ & $\begin{array}{l}150 \\
136\end{array}$ & $\begin{array}{l}3.727 \\
3.471\end{array}$ & $\begin{array}{l}0.948 \\
1.088\end{array}$ & $\begin{array}{l}0.077 \\
0.093\end{array}$ & $\begin{array}{l}\text { Equal variances } \\
\text { assumed } \\
\text { Equal variances } \\
\text { not assumed }\end{array}$ & 2.713 & 0.101 & $\begin{array}{l}2.127 \\
2.112\end{array}$ & $\begin{array}{l}284.000 \\
269.159\end{array}$ & $\begin{array}{l}0.034 \\
0.036\end{array}$ & $\begin{array}{l}0.256 \\
0.256\end{array}$ & $\begin{array}{l}0.120 \\
0.121\end{array}$ \\
\hline
\end{tabular}

Notes:
Scale: 1 = not required at all; 2 = slightly; required; $3=$ moderately required; 4 = required; 5 = highly required 
Table 6: Differences in Perceived Infrastructure Procurement Skills Development Needs - By Location

\begin{tabular}{|c|c|c|c|c|c|c|c|c|c|c|c|c|c|}
\hline \multirow{3}{*}{ Skills } & \multirow{3}{*}{ Location } & \multirow{3}{*}{$\mathrm{N}$} & \multirow{3}{*}{ Mean } & \multirow{3}{*}{$\begin{array}{l}\text { Std. } \\
\text { Dev. }\end{array}$} & \multirow{3}{*}{$\begin{array}{l}\text { Std. Error } \\
\text { Mean }\end{array}$} & \multicolumn{8}{|c|}{ Independent Samples t-test } \\
\hline & & & & & & \multicolumn{3}{|c|}{ Levene's Test for Equality of Variances } & \multicolumn{5}{|c|}{ t-test for Equality of Means } \\
\hline & & & & & & $\begin{array}{l}\text { Equality of } \\
\text { Variances }\end{array}$ & $\mathrm{F}$ & Sig. & $\mathrm{t}$ & $\mathrm{df}$ & $\begin{array}{l}\text { Sig. (2- } \\
\text { tailed) }\end{array}$ & $\begin{array}{l}\text { Mean } \\
\text { Diff. }\end{array}$ & $\begin{array}{l}\text { Std. Error } \\
\text { Diff. }\end{array}$ \\
\hline \multirow{2}{*}{ Creative thinking } & South & 169 & 4.006 & 0.896 & 0.069 & $\begin{array}{l}\text { Equal variances } \\
\text { assumed }\end{array}$ & 10.312 & 0.001 & 3.062 & 284.000 & 0.002 & 0.348 & 0.114 \\
\hline & North & 117 & 3.658 & 1.010 & 0.093 & $\begin{array}{l}\text { Equal variances not } \\
\text { assumed }\end{array}$ & & & 2.996 & 229.827 & 0.003 & 0.348 & 0.116 \\
\hline \multirow{2}{*}{$\begin{array}{l}\text { Contract management } \\
\text { and enforcement }\end{array}$} & South & 170 & 3.724 & 1.141 & 0.088 & $\begin{array}{l}\text { Equal variances } \\
\text { assumed }\end{array}$ & 19.515 & 0.000 & -1.882 & 285.000 & 0.061 & -0.234 & 0.124 \\
\hline & North & 117 & 3.957 & 0.855 & 0.079 & $\begin{array}{l}\text { Equal variances not } \\
\text { assumed }\end{array}$ & & & -1.982 & 282.907 & 0.048 & -0.234 & 0.118 \\
\hline \multirow{2}{*}{$\begin{array}{l}\text { Business case } \\
\text { development }\end{array}$} & South & 169 & 3.544 & 1.035 & 0.080 & $\begin{array}{l}\text { Equal variances } \\
\text { assumed }\end{array}$ & 0.020 & 0.889 & 2.609 & 284.000 & 0.010 & 0.331 & 0.127 \\
\hline & North & 117 & 3.214 & 1.081 & 0.100 & $\begin{array}{l}\text { Equal variances not } \\
\text { assumed }\end{array}$ & & & 2.588 & 242.428 & 0.010 & 0.331 & 0.128 \\
\hline \multirow{2}{*}{$\begin{array}{l}\text { Cross cultural } \\
\text { awareness }\end{array}$} & South & 170 & 3.553 & 1.082 & 0.083 & $\begin{array}{l}\text { Equal variances } \\
\text { assumed }\end{array}$ & 0.333 & 0.564 & 2.407 & 285.000 & 0.017 & 0.314 & 0.130 \\
\hline & North & 117 & 3.239 & 1.088 & 0.101 & $\begin{array}{l}\text { Equal variances not } \\
\text { assumed }\end{array}$ & & & 2.405 & 248.680 & 0.017 & 0.314 & 0.130 \\
\hline \multirow{2}{*}{ Stress management } & South & 170 & 3.729 & 1.108 & 0.085 & $\begin{array}{l}\text { Equal variances } \\
\text { assumed }\end{array}$ & 1.171 & 0.280 & 3.032 & 285.000 & 0.003 & 0.413 & 0.136 \\
\hline & North & 117 & 3.316 & 1.172 & 0.108 & $\begin{array}{l}\text { Equal variances not } \\
\text { assumed }\end{array}$ & & & 3.001 & 240.264 & 0.003 & 0.413 & 0.138 \\
\hline \multirow{2}{*}{$\begin{array}{l}\text { Environmental } \\
\text { management }\end{array}$} & South & 170 & 3.929 & 0.983 & 0.075 & $\begin{array}{l}\text { Equal variances } \\
\text { assumed }\end{array}$ & 0.529 & 0.468 & 2.306 & 285.000 & 0.022 & 0.271 & 0.118 \\
\hline & North & 117 & 3.658 & 0.975 & 0.090 & $\begin{array}{l}\text { Equal variances not } \\
\text { assumed }\end{array}$ & & & 2.309 & 250.705 & 0.022 & 0.271 & 0.118 \\
\hline \multirow{2}{*}{$\begin{array}{l}\text { Health and safety } \\
\text { management }\end{array}$} & South & 170 & 4.094 & 0.981 & 0.075 & $\begin{array}{l}\text { Equal variances } \\
\text { assumed }\end{array}$ & 0.235 & 0.628 & 2.491 & 285.000 & 0.013 & 0.291 & 0.117 \\
\hline & North & 117 & 3.803 & 0.958 & 0.089 & $\begin{array}{l}\text { Equal variances not } \\
\text { assumed }\end{array}$ & & & 2.502 & 253.211 & 0.013 & 0.291 & 0.116 \\
\hline
\end{tabular}

Notes: Scale: $1=$ not required at all; $2=$ slightly; required; $3=$ moderately required; $4=$ required; $5=$ highly required 
Table 7: Suitable Methods for Development of Infrastructure Procurement Skills

\begin{tabular}{|c|c|c|c|c|c|c|c|c|c|c|c|c|}
\hline \multirow{3}{*}{ Skills Development Methods } & \multirow{3}{*}{$\mathrm{N}$} & \multirow{3}{*}{ Mean } & \multirow{3}{*}{$\begin{array}{c}\text { Rank } \\
\text { by } \\
\text { Mean }\end{array}$} & \multirow{3}{*}{$\begin{array}{l}\text { Std. } \\
\text { Dev. }\end{array}$} & \multirow{3}{*}{$\begin{array}{l}\text { Std. } \\
\text { Error } \\
\text { Mean }\end{array}$} & \multicolumn{7}{|c|}{ One-Sample t-test $($ Test Value $=3.5)$} \\
\hline & & & & & & \multirow[t]{2}{*}{$t$} & \multirow[t]{2}{*}{ df } & \multirow{2}{*}{$\begin{array}{l}\text { Sig. } \\
(2- \\
\text { tailed })\end{array}$} & \multirow{2}{*}{$\begin{array}{l}\text { Sig. } \\
(1- \\
\text { tailed })\end{array}$} & \multirow[t]{2}{*}{$\begin{array}{l}\text { Mean } \\
\text { Diff. }\end{array}$} & \multicolumn{2}{|c|}{$\begin{array}{l}95 \% \text { Confidence } \\
\text { Interval of the } \\
\text { Difference }\end{array}$} \\
\hline & & & & & & & & & & & Lower & Upper \\
\hline Conferences and workshop attendance & 287 & 4.108 & 1 & 0.953 & 0.056 & 10.810 & 286 & 0.000 & 0.000 & 0.608 & 0.497 & 0.719 \\
\hline Networking and sharing ideas with other professionals & 287 & 4.042 & 2 & 0.872 & 0.051 & 10.526 & 286 & 0.000 & 0.000 & 0.542 & 0.440 & 0.643 \\
\hline On-the-job-training & 287 & 4.017 & 3 & 0.906 & 0.053 & 9.672 & 286 & 0.000 & 0.000 & 0.517 & 0.412 & 0.623 \\
\hline Further / Higher academic degree courses & 287 & 4.000 & 4 & 1.087 & 0.064 & 7.792 & 286 & 0.000 & 0.000 & 0.500 & 0.374 & 0.626 \\
\hline Work team retreats & 287 & 3.986 & 5 & 0.861 & 0.051 & 9.565 & 286 & 0.000 & 0.000 & 0.486 & 0.386 & 0.586 \\
\hline Short continuous professional development (CPD) courses & 287 & 3.920 & 6 & 0.945 & 0.056 & 7.531 & 286 & 0.000 & 0.000 & 0.420 & 0.310 & 0.530 \\
\hline More job responsibility & 286 & 3.874 & 7 & 0.961 & 0.057 & 6.580 & 285 & 0.000 & 0.000 & 0.374 & 0.262 & 0.486 \\
\hline Exchange visits and study tours & 287 & 3.843 & 8 & 0.979 & 0.058 & 5.941 & 286 & 0.000 & 0.000 & 0.343 & 0.229 & 0.457 \\
\hline Coaching, mentoring and shadowing & 287 & 3.746 & 9 & 0.954 & 0.056 & 4.361 & 286 & 0.000 & 0.000 & 0.246 & 0.135 & 0.357 \\
\hline $\begin{array}{l}\text { Self-learning through manuals, academic or professional } \\
\text { journals }\end{array}$ & 286 & 3.678 & 10 & 1.016 & 0.060 & 2.967 & 285 & 0.003 & 0.002 & 0.178 & 0.060 & 0.297 \\
\hline In-house training courses & 288 & 3.649 & 11 & 1.150 & 0.068 & 2.203 & 287 & 0.028 & 0.014 & 0.149 & 0.016 & 0.283 \\
\hline Job rotation or secondment & 288 & 3.486 & 12 & 1.062 & 0.063 & -.222 & 287 & 0.825 & 0.412 & -0.014 & -0.137 & 0.109 \\
\hline Internships and placements & 288 & 3.444 & 13 & 1.051 & 0.062 & -.897 & 287 & 0.371 & 0.185 & -0.056 & -0.177 & 0.066 \\
\hline Apprenticeships & $\begin{array}{l}287 \\
288\end{array}$ & $\begin{array}{l}3.418 \\
3.358\end{array}$ & $\begin{array}{l}14 \\
15\end{array}$ & 1.167 & 0.069 & $\begin{array}{l}-1.188 \\
-2\end{array}$ & 286 & $\begin{array}{l}0.236 \\
0.026\end{array}$ & $\begin{array}{l}0.118 \\
0.013\end{array}$ & $\begin{array}{l}-0.082 \\
-0.142\end{array}$ & $\begin{array}{l}-0.218 \\
-0.268\end{array}$ & $\begin{array}{r}0.054 \\
-0.017\end{array}$ \\
\hline
\end{tabular}


